\title{
Intimate Partner Violence: An Overview of the Existing Theories, Conceptual Frameworks, and Definitions
}

\author{
Anastasia S. Burelomova ${ }^{\mathrm{a}, \mathrm{b} *}$, Marina A. Gulina ${ }^{\mathrm{a}, \mathrm{b}}$, \\ Olga A. Tikhomandritskaya ${ }^{\mathrm{a}}$ \\ ${ }^{a}$ Lomonosov Moscow State University, Moscow, Russia \\ ${ }^{b}$ City University of London, London, United Kingdom \\ *Corresponding author: E-mail: Anastasia.burelomova.1@city.ac.uk
}

Background: Intimate Partner Violence (IPV), also known as domestic violence, spousal abuse, and relationship violence, among other names, is becoming a widely recognized social and public health problem. Theory and practice suggest it is vital that the issue be addressed comprehensively in both the healthcare and socio-legal contexts. The theoretical perspectives underlying inquiries into the nature and etiology of the IPV phenomenon are of fundamental importance in promoting our understanding of how to prevent, reduce, or eliminate the problem. In order to integrate various aspects of knowledge about the phenomenon, it is important to consider and evaluate the approaches to IPV currently prevalent in the field.

Objectives: The present article aims to provide a critical overview of the existing theories, methodological frameworks, typologies, and definitions of Intimate Partner Violence.

Design: The present paper reviews the international literature on the conceptual frameworks and definitions of IPV. First, it draws on the conceptual frameworks of violence; it then reviews relevant theories and definitions of IPV considered from sociocultural, individual, and integrative perspectives. The disparities, limitations, and explanatory powers of these theories, as well as their clinical and research applications, are discussed in an attempt to bring more clarity into the current state of understanding in the field.

Results and Conclusions: Our review suggests that there is no universally accepted definition of IPV, nor a conceptual framework that would encompass the complexity of the phenomenon. Some of the theoretical frameworks for studying IPV appear to provide potential advantages over others, but their empirical viability has yet to be determined. We argue that, due to the complex multifaceted nature of IPV, a narrow theoretical stance might exclude a variety of exploratory factors and limit understanding of the phenomenon.

Key words: Intimate Partner Violence (IPV); theory of IPV; domestic violence; spouse abuse, interpersonal violence; violence against women (VAW). 


\section{Introduction}

Intimate Partner Violence (IPV) continues to be a major health and human rights issue around the globe. Although it has been recognized that IPV can be perpetuated and suffered by all population groups (McFeely, Whiting, Lombard, \& McGowan, 2013; Robinson, 2006; Smith, 2012), its occurrence is significantly more often documented in women rather than men; 25 to $54 \%$ of women report exposure to various types of IPV during their lifetimes (Thompson et al., 2006). According to official statistics, two women are killed every week in England and Wales due to IPV (Home Office, 2015). In Russia, statistics on IPV appear to be more scarce, gender neutral, and hard to obtain (Zabelina, 2008), making it barely possible to draw any conclusions. Furthermore, the social and legal protection systems of both countries call for improvement when it comes to preventing IPV, or dealing with its consequences (Burman \& Chantler, 2005; Bryantseva, 2007; Freeman, 1980; Popova, 2012).

Numerous studies suggest a variety of factors that potentially affect disclosure of IPV and hinder women's help-seeking. Those include sociodemographic factors (Barrett \& Pierre, 2011) and the degree of women's readiness for change (Alexander, Tracy, Radek, \& Koverola, 2009), as well as cultural (Nagae \& Dancy, 2010), psychological (Petersen, Moracco, Goldstein, \& Clark, 2005), and financial (Feder, Hutson, Ramsay, \& Taket, 2006) factors, lack of knowledge about IPV (Chang et al., 2006), and many more. In addition, there is a growing body of research suggesting that a substantial proportion of women exposed to IPV, besides suffering from poor physical health, often present with mental health problems, including depression, anxiety, phobias, post-traumatic stress disorder (PTSD), substance abuse, and suicidality (Bonomi et al., 2006; Ellsberg, Jansen, Heise, Watts, \& Garcia-Moreno, 2008; Nixon, Resick, \& Nishith, 2004; Plichta \& Falik, 2001; Romito, Molzan Turan, \& De Marchi, 2005).

Discussion of human violence, both in general and specific contexts, raises questions about the meaning attributed to the term violence. Although the meaning might seem obvious, there is little consensus among researchers on how to define violence and its different "forms" or "types" (Barocas, Emery, \& Mills, 2016; Kilpatrick, 2004; Tjaden, 2004). Winstok (2007) suggests that disparities around the definition of violence could be a result of conflicting ideologies, perspectives, theories, and methodologies for studying violence, its perpetrators, and its victims. Therefore, in order to integrate the various aspects of knowledge about the phenomenon, it is important to critically evaluate the prevalent approaches to Intimate Partner Violence (IPV) in the field.

\section{Conceptual framework and definition of violence}

Prior to exploring the meaning and conceptual frameworks for understanding IPV, we must discuss what we mean by the term violence. The existing literature proposes a number of ways to define it (Åström, Bucht, Eisemann, Norberg, \& Saveman, 2002; Barnett, Miller-Perrin, \& Perrin, 2005; O’Moore, 2006; Rhatigan, Moore, \& Street, 2005; Smith-Pittman \& McKoy, 2999; WHO, 1996a; Winstok, 2007). A comprehensive analysis of violence and its definition, incorporating all its forms and the various aspects contributing to the phenomenon, would be outside 
the scope of this discussion, which is focused specifically on IPV. However, it is important to briefly outline the conceptual framework and definition of violence which we adopted in this article, to better situate the IPV phenomenon within the general concept of violence.

The present paper adopts the following definition of violence proposed by the World Health Organization:

The intentional use of physical force or power, threatened or actual, against oneself, another person, or against a group or community, that either results in or has a high likelihood of resulting in injury, death, psychological harm, maldevelopment or deprivation. (WHO, 1996b, cited in Krug, Mercy, Dahlbers, \& Zwi, 2002, p. 1084)

Like other researchers in the field, we use the terms violence and abuse interchangeably in the present article (Barnett et al., 2005; Capaldi, Knoble, Shortt, \& Kim, 2012; Finkelhor, Turner, Ormrod, \& Hamby, 2010; Hegarty, Hindmarsh, \& Gilles, 2000; Henderson, 2002; Hoffman \& Edwards, 2004; Johnson, 2006; Moyer, 2013). The terms batterer, offender, perpetrator, and abuser are also used interchangeably (Follingstad \& Rogers, 2014; Jin, Eagle, \& Yoshioka, 2007; Moyer, 2013; Vanderende et al., 2016; Wareham, Boots, \& Chavez, 2009).

The current article adopts the typology of violence proposed by Krug et al. (2002), suggest that violence can be generally divided into three main categories according to characteristics of those committing the violent act: self-directed, interpersonal, and collective. Each of the proposed categories of violence is divided into subcategories according to the nature of the violent acts (physical, sexual, psychological, deprivation, or neglect).

Self-directed violence can be subdivided into suicidal behavior and self-abuse. The former includes suicidal thoughts, attempted suicides, and completed suicides. Self-abuse includes acts such as self-mutilation.

Interpersonal violence can also be divided into two subcategories: 1) family and intimate partner violence-violence mainly between members of the family, as well as intimate partners; and 2) community violence-violence between people who are unrelated, and may or may not know each other. The family and IPV subgroup includes such forms of violence as child abuse, elder abuse, and IPV. The community violence subgroup includes random acts of violence, rape, and sexual assault by strangers, and violence at institutional settings such as workplaces, schools, prisons, or nursing homes.

Collective violence can be subdivided into three categories: social, political, and economic. Unlike the first two categories, collective violence can be referred to through its possible motivation. For instance, crimes of hate committed by organized groups, or terrorist acts, could be identified as a type of collective violence committed to advance a particular social agenda. Examples of political violence could include war and related violent conflicts. Economic violence includes attacks by larger groups motivated by an economic agenda, such as denying access to essential services, and attacks carried out to disrupt economic activity or create economic division and fragmentation.

Krug and his colleagues emphasize the complexity of the violence phenomenon and the interconnected nature of different types of violence. They highlight the importance of examining the links between different types of violence for po- 
tential prevention and collaboration between groups of professionals working on preventing them (El-Bassel, Witte, Wada, Gilbert, \& Wallace, 2001; Hindin, Kishor, \& Ansara, 2008; Kruh, Frick, \& Clements, 2005; LeBlanc \& Kelloway, 2002; Swahn \& Donovan, 2004; Vanderende et al., 2016).

We distinguish Intimate Partner Violence from domestic violence. We suggest that the term domestic violence be used as a broad term (Barocas et al., 2016) that includes but is not limited to Intimate Partner Violence; it may also involve violence against or between other members of the family who might or might not live together (e.g. adult/child, elder/adult, child/elder, child/parent, or siblings).

For the purposes of this paper, it is particularly important to conceptualize IPV as a subcategory of interpersonal violence. We view IPV as a type of interpersonal violence, occurring in a family/partner setting and directed towards an intimate partner, as we discuss in detail throughout the following sections.

\section{Sociocultural theories of IPV}

\section{Feminist theory}

Feminist theory, often referred to as the Feminist Model, aims to understand violent relationships through examining the sociocultural context in which these relationships occur. Supporters of this theory often view gender inequality and sexism within patriarchal societies as the main causes of IPV (Bell \& Naugle, 2008). In short, they argue that IPV is primarily a problem of men's violence against women being caused by societal rules and patriarchal beliefs encouraging male dominance and female subordination ${ }^{1}$ (Abrar, Lovenduski, \& Margetts, 2000; Bell \& Naugle, 2008; Yllö, 1988). Proponents of the feminist theory suggest that men often use different tactics, including physical violence, to exert control and dominance over women and their families (Dobash \& Dobash, 1978), and that women's violent behavior towards their male partners should be understood as self-defense, retaliation, or pre-emption for male violence. Thus, they argue, such violence against women should be studied within the wider context of patriarchy, and the intentions associated with the violent event, by applying non-patriarchal qualitative methods (McMahon \& Pence, 1996).

The feminist theoretical tradition views violence towards women as a special case, different from other forms of violence and other forms of crime (Dobash \& Dobash, 2004). Therefore, it says that treatment for the problem should be concerned with educating men and addressing their patriarchal beliefs and domineering behavior toward women, while the ultimate goal would be overturning patriarchal social structures to prevent, reduce, and eliminate violence against women (Dutton, 2011).

1 "It behooves the husband to punish his wife and use fear in private: punishing, taking pity, and talking, and lovingly teaching, and judging. And if the wife, or the son, or the daughter does not listen to a word or punishment, then flog them with a whip, taking in consideration their fault, in private, and not in front of people and, to teach, to calm down and take pity and not to be angry with each other. And for every fault not to beat on the ear and on the face, nor with a fist under the heart. Neither kick nor with a staff pound, not to beat with iron or wood. Whoever in passion or from sorrow beats, many ailments come from that - blindness and deafness, and the arm and leg and finger can be dislocated. And in pregnant women and children in the womb there is damage; and punishment with a whip is reasonable, and it's painful, and scary and healthy but not harmful" (Domostroy/ Ed by. V. Kolesov, EKSMO, 2007). 
Some of the studies supporting the feminist theory indicate higher rates of assaults against wives in husband-dominant families, families where husbands hold traditional "gender-role" attitudes, or where there are great discrepancies between the acceptance of patriarchal values between a husband and a wife (Hunnicutt, 2009; Leonard \& Senchak, 1996; Yllö, 1983).

Feminist research and some studies reporting significantly higher prevalence of IPV victimization in women have been widely criticized for their sample selection. For instance, recruiting women from shelters, refuges, or emergency departments (Dutton, 2011), and then extrapolating their findings from such studies to the general population (Dixon \& Graham-Kevan, 2011). In addition, qualitative and correlation studies are often referred to as evidence of a relationship between male patriarchal values and physical violence towards their female partners (Bell \& Naugle, 2008). However, meta-analytic reviews do not provide support for such a relationship (Sugarman \& Frankel, 1996), or for patriarchy being the most significant risk factor for IPV (O'Leary, Smith Slep, \& O'Leary, 2007).

\section{Power theory}

Power theorists suggest that the origins of violence are rooted not only in the culture, but also in the family structures (Straus, 1977a). Gender inequality, and social acceptance of violence and family conflict, are assumed to interact, and lead to the development and maintenance of IPV. It is presumed that individuals employ violence to settle conflicts within the family and between intimate partners, because this way of addressing conflicts has been learned in childhood by either witnessing or experiencing physical abuse (Straus, 1977b). Power theorists suggest that power imbalances between partners may increase tension within the family unit and consequently increase the risk of IPV (Sagrestano, Heavey, \& Christensen, 1999).

There were a number of studies reporting higher IPV rates in families with high rates of stress and conflict (Cascardi \& Vivian, 1995; Leonard \& Senchak, 1996; Mihalic \& Elliott, 2005).

The power theory addresses a gender-inclusive perspective and encourages research into examining both the male's and female's use of IPV. Such a perspective incorporates a variety of theoretical standpoints guiding research to understand why heterosexual and homosexual men and women perpetrate IPV.

Exploring the feminist and family violence perspectives: Violence against women (VAW) vs. Intimate Partner Violence (IPV)

Conceptions of violence against women can be broadly categorized within two traditions which are only partially integrated (Gordon, 2000). The first one evolved from advocacy movements for victims of sexual assaults and domestic violence, and the other from social and behavioral research on sexual assault and family violence (Winstok, 2007). The distinction between the terms domestic and family violence is not random. "Domestic" refers to structure, and "family" to relationships. Winstok (2007) suggests that the term "domestic" violence might imply a feminist perspective, whilst the term "family" violence might be derived from social and family research, and be manifested in the works of researchers on family conflict. 
Different theoretical standpoints would produce very different definitions of violence in intimate relationships. As mentioned earlier, Straus (1979), one of the prominent researchers following family violence approach, viewed violence as a non-legitimate tactic individuals employ to settle interpersonal conflicts in general, and between intimate partners in particular. He and his colleagues defined violence as "... an act carried out with the intention of or perceived intention of causing physical pain or injury to another person' (Straus, Gelles, \& Steinmentz, 1981, p. 20). Their work was heavily criticized by feminist scholars who opposed their lack of attention to social context, their symmetrical approach to gender, and the scope of violence addressed (Johnson, 1995).

Following the feminist tradition, DeKeseredy (1997) proposed the following definition of woman abuse in intimate relationships:

Woman abuse is the misuse of power by a husband, intimate partner (whether male or female), ex-husband, or ex-partner against a woman, resulting in a loss of dignity, control, and safety as well as a feeling of powerlessness and entrapment experienced by the woman who is the direct victim of on-going or repeated physical, psychological, economic, sexual, verbal, and/or spiritual abuse. Woman abuse also includes persistent threats or forcing women to witness violence against their children, other relatives, friends, pets, and/or cherished possessions by their husbands, partners, ex-husbands, or ex-partners (DeKerseredy, 1997, p. 5).

This definition is broader than the one by Straus and his colleagues, and encompasses various aspects of violence. It clearly defines the victim and the aggressor, sees violence as a misuse of power, and defines the outcomes of violence; however, it lacks the identifying criteria, which makes it difficult to evaluate (Winstok, 2007).

In an attempt to integrate the perceptions of both feminist and family researchers, Johnson (2001) focused on discussing whether only men are violent in intimate relationships, and lead women to perpetrate violence "in defense" (feminist perspective), or whether women are also initiating violence (the standpoint of family conflict researchers). He proposed that the perspectives of both feminist and family researchers can be appropriate in explaining IPV (Abbott, Johnson, KoziolMcLain, \& Lowenstein, 1995). This discussion produced a comprehensive typology whereby IPV can be classified into five qualitatively different types: coercive controlling behavior, violent resistance, situational couple violence, mutual violent control violence, and separation-instigated violence (Beck, Anderson, O’Hara, \& Benjamin, 2013).

The public health approach is also in a way a compromise between the two perspectives. It defines IPV as "behavior within an intimate relationship that causes or has the potential to cause physical, sexual, or psychological harm, including acts of physical aggression, sexual coercion, psychological abuse, and controlling behaviors" (Garcia-Moreno et al., 2015, p. 1686). This definition considers violence mostly within the framework of distinct categories: physical, psychological, and sexual (Gordon, 2000; Löbmann, Greve, Wetzels, \& Bosold, 2003). However, it has to be noted that if physical aggression seems to be a relatively clear category, the other two types, especially psychological aggression, are subject to disagreement between the different schools of thought, and even within each school (Winstok, 2007). This aspect will be further explored in the sections below. 


\section{Individual theories of IPV}

\section{Social learning theory}

As in the power theory, social learning theorists suggest that violent ways of settling family conflicts are often learned through observing parental and peer relationships during childhood (Bandura, 1973; Mihalic \& Elliott, 2005; Wareham et al., 2009). They propose that victims and perpetrators of IPV have either witnessed or experienced physical abuse during childhood, resulting in their developing acceptance or tolerance of violence within the family (Jin et al., 2007; Lewis \& Fremouw, 2001; Vung \& Krantz, 2009).

There are a number of studies reporting that witnessing or experiencing abuse during childhood might be associated with future IPV perpetration or victimization in adulthood (Berzenski \& Yates, 2010; Parks, Kim, Day, Garza, \& Larkby, 2011; Shook, Gerrity, Jurich, \& Segrist, 2000; Whitfield, Anda, Dube, \& Felitti, 2003). It has been suggested that whether or not violence continues into adulthood depends on the context and consequences associated with violence in peer and dating relationships during youth (Daigneault, Hébert, \& McDuff, 2009; Riggs, Caulfield, \& Street, 2000).

\section{Background/situational model}

Expanding on social learning theory, Riggs and O'Leary (1996) developed a "model of courtship aggression" to explain a form of IPV. The model describes two general components which contribute to the development and maintenance of courtship aggression: background and situational factors. The background component refers to historical, societal, and individual characteristics which determine future aggression. These factors might include a history of childhood abuse; exposure to violence in childhood; personality characteristics; a history of the use of aggression; psychopathology; social norms; and attitudes towards aggression as means of resolving conflicts.

The situational component refers to factors setting the stage for violence to occur. Those might include expectations of the outcomes of the violence; interpersonal conflict; intimacy levels; substance abuse; or lack of problem-solving skills. The interaction between these factors might affect conflict intensity, and therefore determine whether or not the violence will occur (Riggs \& O'Leary, 1996). It has been reported that such factors as witnessing violence, parental aggression, and attitudes toward the use of aggression were predictive of IPV occurrence, while substance abuse, one's partner's aggression, and the degree of interpersonal conflict appeared to have had an impact on courtship aggression (Gwartney-Gibbs, Stockard, \& Bohmer, 1987; Riggs \& O'Leary, 1996; White \& Koss, 1991; White, Merrill, \& Koss, 2001).

\section{Personality/typology theories}

Researchers have attempted to identify the psychopathology and personality traits that might affect a person's susceptibility to perpetrate IPV. Holtzworth-Munroe and Stuart (1994) proposed the Developmental Model of Batterer Subtypes through reviewing 15 previous batterer typologies for common themes across classification metrics. 
Three dimensions of severity, generality of violence, and psychopathology/ personality disorder were suggested to classify three main types of male batterer: family only, generally violent/antisocial, and dysphoric/borderline. Later on, an additional subtype defined as a low-level antisocial batterer was identified (Holtzworth-Munroe, Meehan, Herron, Rehman, \& Stuart, 2000). It was suggested that generic/prenatal factors, early childhood experiences, and peer experience would affect the development of the variables most closely associated with IPV perpetration. Those include attachment to others, impulsivity, social skills level, and attitudes toward women and violence (Holtzworth-Munroe \& Stuart, 1994).

This theory has been successfully tested by various studies (Dixon \& Browne, 2003; Holtzworth-Munroe, 2000; Langhinrichsen-Rohling, Huss, \& Ramsey, 2000; Waltz, Babcock, Jacobson, \& Gottman, 2000). Research exploring typologies of female perpetrators has found similarities to male offenders (Babcock, Miller, \& Siard, 2003; Bender \& Roberts, 2007; Dixon \& Browne, 2003).

Other researchers have developed alternative batterer typologies. Although these typologies categorize subtypes of perpetrators through different lenses, most of them define two or three different subtypes. Some of them focus on behavioral, physiological, or psychological characteristics, whilst offering distinct perspectives on the motives and patterns behind the subtypes of perpetrators (Gondolf, 1988; Gottman, Jacobson, rushe, \& Shortt, 1995; Hamberger \& Hastings, 1986; Hamberger, Lohr, Bonge, \& Tolin, 1996; Johnson, 1995). Such discrepancies make it difficult to synthesize these typologies, or even make comparisons across them (Bender \& Roberts, 2007). In an attempt to address these difficulties, Chiffriller, Hennessy, and Zappone (2006) examined clusters of offenders in a large study focused on behavioral and personality characteristics, whereby they distinguished five subtypes incorporating previous typologies: 1 ) pathological batterers; 2) sexually violent batterers; 3) generally violent batterers; 4) psychologically violent batterers; and 5) family-only batterers.

\section{Typology of IPV by type of violence}

Another framework for classifying IPV is by the form of violence or abuse (terms are used interchangeably in this study). Three main categories-physical, sexual, and psychological-are frequently used in the various studies (Devries et al., 2013; Ellsberg et al., 2008; García-Moreno et al., 2015). Some researchers have identified other categories such as financial or social abuse, but it is not clear whether those categories can be considered to be separate dimensions of IPV (Ali, Dhingra, \& McGarry, 2016).

\section{Physical violence}

Physical violence refers to the use of physical force to inflict pain, injury, or physical suffering on a victim. Examples of physical violence might include beating, slapping, kicking, pushing, shoving, stabbing, dragging, scratching, choking, burning, and threatening or using a gun, knife, or another weapon (Garcia-Moreno, Heise, Jansen, Ellsberg, \& Watts, 2005). 


\section{Sexual violence}

Sexual violence is defined as "any sexual act, attempt to obtain a sexual act, unwanted sexual comments or advances, acts to traffic, or other coercive actions directed against a person's sexuality by any person, irrespective of relationship to the victim, in any setting, including but not limited to home and work" (Garcia-Moreno et al., 2015, p. 1686). In the context of IPV, sexual violence refers to forcing a partner, who did not want it, to have sexual intercourse, or do any sexual act that they found degrading or humiliating; harming them during sex; or forcing them to have sex without protection (WHO, 2013).

\section{Psychological violence}

Psychological violence refers to acting in an offensive, degrading, or humiliating manner toward another, usually verbally, and may include threats, ridicule, withholding affection, and restrictions (e.g. social isolation, financial control (Maiuro, 2001). Some examples of psychological violence in IPV perpetrated by men against women can include verbal abuse, name-calling, blackmailing, saying or doing something to make a person feel embarrassed, threats to beat a woman or children, restricting access to friends and family, and restricting independence and access to information, education, or health services (WHO, 2002, 2013).

\section{Integrative frameworks of IPV}

The brief reviews in the previous sections did not aim at exhausting the scope of studies on violence, but to demonstrate the complexity and disparity of the issues encountered when one attempts to define IPV and the implications of its definition for theory and practice. Many researchers have argued the need for more comprehensive theories of IPV (Barocas et al., 2016; Sellers, Cochran, \& Branch, 2005; Whitaker et al., 2006; Wilkinson \& Hamerschlag, 2005). It has been suggested that the theories should take into account the perspective of both the victim and the perpetrator, while integrating the standpoints from various academic disciplines such as psychology, sociology, and criminal justice (Rhatigan et al., 2005). Furthermore, some authors argue that IPV theories should be more ideographic in nature, taking into consideration the significant heterogeneity of IPV (Bogat, Levendosky, \& von Eye, 2005), as well as addressing the context and proximal events associated with IPV (Bell \& Naugle, 2008; Bogat et al., 2005; Wilkinson \& Hamerschlag, 2005; Winstok, 2007).

Bell and Naugle (2008) developed a theoretical framework for IPV, which offers a contextual analysis of IPV perpetration. This framework incorporates empirical findings and theories on IPV, drawing heavily from Behavior Analytic (Myers, 1995), Social Learning (Bandura, 1973) and Background/Situation (Riggs \& O'Leary, 1996) theories. They hypothesize that multiple contextual units are implicated in the perpetration of IPV: target behavior (e.g. physical, sexual or psychological aggression); antecedents of target behavior; discriminative stimuli (e.g. presence/absence of others); motivating factors (e.g. substance abuse, emotional distress); behavioral repertoire (e.g. coping skills, anger management skills); verbal rules (e.g. beliefs about violence or women); and consequences (reinforcement and punishment). A number of potentially relevant proximal variables are identified 
for each unit. Bell and Naugle (2008) argue that this contextual framework has the potential to offer significant improvements for conceptualizing IPV, as well as in IPV prevention and treatment. However, it is yet to be empirically tested.

Winstok (2007) developed an Integrative Structural Model of Violence (ISMV) that might be helpful in understanding interpersonal violence in general, and IPV in particular, through a set system of criteria and relationships between them. He defines interpersonal violence as "a non-legitimate forceful tactic intentionally employed by one party to cause physical and/or psychological harm to the other in the attempt to control a situation" (Winstok, 2007, p. 352).

ISMV consists of four levels of reference: violent behavior (motive, action itself, consequences); the situation in which the violence occurs; the relationships between the parties; and the sociocultural context of the relationships. For instance, the ISMV provides a framework for formulating the definition of IPV perpetrated by men against their female intimate partners as follows:

Violence is a non-legitimate, forceful (belligerent) tactic a man uses anytime anywhere against a woman with whom he has or had an intimate relationship. This tactic is part of the man's perception of a given situation and of his attempt to control it. The tactic is motivated by the man's need to prevent, balance, or gain something in his or other persons' interpersonal or social realities, as he perceives them. This tactic consists of at least one action of a physical, aural, or visual orientation employed by the man to (intentionally) harm the woman. Using this tactic can cause the woman at least one form of harm of a physical, social, or economic nature, including harming her self-esteem or self-, social, or public image in the short or long term (Winstok, 2007, p. 357).

The above definition gives content to the structural component of the model, and includes reference to the meaning of violence, situational context, motive, action, and consequences; this appears to be a detailed framework for conceptualizing the complexity of IPV.

\section{Conclusion}

Overall, the theory and research on IPV demonstrates the multifaceted and complex nature of the phenomenon. Therefore, it is important that a broad range of factors be considered when assessing and addressing the problem. A narrow theoretical focus might exclude potentially important exploratory factors (Dixon \& Graham-Kevan, 2011).

It appears that the existing theories of IPV are limited in their ability to improve the clinical efficacy of IPV interventions, as well as to provide a sufficient basis for conducting research. Furthermore, the variety of competing IPV theories has led to a divide among researchers in the field arising from the overall political and social climate under which those theories have been developed and research conducted. As a result, some of the existing IPV theories are limited as to their ability to explain contradictory findings or the heterogeneity of IPV phenomenon.

To date, there is neither a universally accepted definition of IPV, nor there is a conceptual framework that would encompass the complexity of the phenomenon. Some of the theoretical frameworks of IPV appear to provide a number of potential advantages over others; however, their empirical viability is yet to be determined. 
Although initial steps have been taken to conceptualize and explore the context of IPV, we seem to be in need of sufficient progress in the field so that the researchers can systematically examine the context and complexity of IPV in theory and practice.

\section{References}

Abbott, J., Johnson, R., Koziol-McLain, J., \& Lowenstein, S. R. (1995). Domestic violence against women: incidence and prevalence in an emergency department population. JAMA, 273(22), 1763-1767. https://doi.org/10.1001/jama.1995.03520460045033

Abrar, S., Lovenduski, J., \& Margetts, H. (2000). Feminist ideas and domestic violence policy change. Political studies, 48(2), 239-262. https://doi.org/10.1111/1467-9248.00258

Alexander, P. C., Tracy, A., Radek, M., \& Koverola, C. (2009). Predicting stages of change in battered women. Journal of Interpersonal Violence, 24(10), 1652-1672. https://doi. org $/ 10.1177 / 0886260509331494$

Ali, P. A., Dhingra, K., \& McGarry, J. (2016). A literature review of intimate partner violence and its classifications. Aggression and Violent Behavior, 31, 16-25. https://doi.org/10.1016/j. avb.2016.06.008

Åström, S., Bucht, G., Eisemann, M., Norberg, A., \& Saveman, B. I. (2002). Incidence of violence towards staff caring for the elderly. Scandinavian Journal of Caring Sciences, 16(1), 66-72. https://doi.org/10.1046/j.1471-6712.2002.00052.x

Babcock, J. C., Miller, S. A., \& Siard, C. (2003). Toward a typology of abusive women: Differences between partner-only and generally violent women in the use of violence. Psychology of Women Quarterly, 27(2), 153-161. https://doi.org/10.1111/1471-6402.00095

Bandura, A. (1973). Aggression: A social learning analysis: Prentice-Hall.

Barnett, O., Miller-Perrin, C. L., \& Perrin, R. D. (2005). Family violence across the lifespan: An introduction: Sage Publications, Inc.

Barocas, B., Emery, D., \& Mills, L. G. (2016). Changing the Domestic Violence Narrative: Aligning Definitions and Standards. Journal of Family Violence, 31(8), 941-947. https://doi. org/10.1007/s10896-016-9885-0

Barrett, B. J. \& Pierre, M. S. (2011). Variations in women's help seeking in response to intimate partner violence: Findings from a Canadian population-based study. Violence Against Women, 17(1), 47-70. https://doi.org/10.1177/1077801210394273

Beck, C. J., Anderson, E. R., O’Hara, K. L., \& Benjamin, G. A. H. (2013). Patterns of intimate partner violence in a large, epidemiological sample of divorcing couples. Journal of Family Psychology, 27(5), 743. https://doi.org/10.1037/a0034182

Bell, K. M. \& Naugle, A. E. (2008). Intimate partner violence theoretical considerations: Moving towards a contextual framework. Clinical Psychology Review, 28(7), 1096-1107. https://doi. org/10.1016/j.cpr.2008.03.003

Bender, K. \& Roberts, A. R. (2007). Battered women versus male batterer typologies: Same or different based on evidence-based studies? Aggression and Violent Behavior, 12(5), 519530. https://doi.org/10.1016/j.avb.2007.02.005

Berzenski, S. R. \& Yates, T. M. (2010). A developmental process analysis of the contribution of childhood emotional abuse to relationship violence. Journal of Aggression, Maltreatment \& Trauma, 19(2), 180-203. https://doi.org/10.1080/10926770903539474

Bogat, G. A., Levendosky, A. A., \& von Eye, A. (2005). The Future of Research on Intimate Partner Violence: Person-Oriented and Variable-Oriented Perspectives. American Journal of Community Psychology, 36(1-2), 49-70. https://doi.org/10.1007/s10464-005-6232-7 
Bonomi, A. E., Thompson, R. S., Anderson, M., Reid, R. J., Carrell, D., Dimer, J. A., \& Rivara, F. P. (2006). Intimate Partner Violence and Women's Physical, Mental, and Social Functioning. American Journal of Preventive Medicine, 30(6), 458-466. https://doi.org/10.1016/j. amepre.2006.01.015

Bryantseva, M. (2007). Sotsial'no-pravovaya zashchita ot domashnego nasiliya v sem'ye v Sovremennoy Rossii [Social and legal protection against domestic violence in the family in Modern Russia]. Sotsial'naya politika i sotsiologiya (1), 91-98.

Burman, E. \& Chantler, K. (2005). Domestic violence and minoritization: legal and policy barriers facing minoritized women leaving violent relationships. International Journal of Law and Psychiatry, 28(1), 59-74. https://doi.org/10.1016/j.ijlp.2004.12.004

Capaldi, D. M., Knoble, N. B., Shortt, J. W., \& Kim, H. K. (2012). A systematic review of risk factors for intimate partner violence. Partner Abuse, 3(2), 231-280. https://doi.org/10.1891/19466560.3.2.231

Cascardi, M. \& Vivian, D. (1995). Context for specific episodes of marital violence: Gender and severity of violence differences. Journal of Family Violence, 10(3), 265-293. https://doi. org/10.1007/BF02110993

Chang, J. C., Dado, D., Ashton, S., Hawker, L., Cluss, P. A., Buranosky, R., \& Scholle, S. H. (2006). Understanding behavior change for women experiencing intimate partner violence: Mapping the ups and downs using the stages of change. Patient Education and Counseling, 62(3), 330-339. https://doi.org/10.1016/j.pec.2006.06.009

Chiffriller, S. H., Hennessy, J. J., \& Zappone, M. (2006). Understanding a new typology of batterers: Implications for treatment. Victims and Offenders, 1(1), 79-97. https://doi. org $/ 10.1080 / 15564880500263182$

Daigneault, I., Hébert, M., \& McDuff, P. (2009). Men's and women's childhood sexual abuse and victimization in adult partner relationships: A study of risk factors. Child Abuse \& Neglect, 33(9), 638-647. https://doi.org/10.1016/j.chiabu.2009.04.003

DeKeseredy, W. (1997). Woman abuse: A sociological story. Toronto: Harcourt Brace.

Devries, K. M., Mak, J. Y., Garcia-Moreno, C., Petzold, M., Child, J. C., Falder, G., . . Rosenfeld, L. (2013). The global prevalence of intimate partner violence against women. Science, 340(6140), 1527-1528. https://doi.org/10.1126/science.1240937

Dixon, L. \& Browne, K. (2003). The heterogeneity of spouse abuse: A review. Aggression and Violent Behavior, 8(1), 107-130. https://doi.org/10.1016/S1359-1789(02)00104-0

Dixon, L. \& Graham-Kevan, N. (2011). Understanding the nature and etiology of intimate partner violence and implications for practice and policy. Clinical Psychology Review, 31(7), 1145-1155. https://doi.org/10.1016/j.cpr.2011.07.001

Dobash, R. E. \& Dobash, R. P. (1978). Wives: The appropriate victims of marital violence. Victimology.

Dobash, R. P., \& Dobash, R. E. (2004). Women's violence to men in intimate relationships working on a puzzle. The British Journal of Criminology, 324-349.

Dobash, R. P., Dobash, R. E., Wilson, M., \& Daly, M. (1992). The myth of sexual symmetry in marital violence. Social Problems, 39(1), 71-91. https://doi.org/10.1093/bjc/azh026

Dutton, D. G. (2011). Rethinking domestic violence: UBC Press.

El-Bassel, N., Witte, S. S., Wada, T., Gilbert, L., \& Wallace, J. (2001). Correlates of partner violence among female street-based sex workers: substance abuse, history of childhood abuse, and HIV risks. AIDS patient care and STDs, 15(1), 41-51. https://doi. org/10.1089/108729101460092

Ellsberg, M., Jansen, H. A. F. M., Heise, L., Watts, C. H., \& Garcia-Moreno, C. (2008). Intimate partner violence and women's physical and mental health in the WHO multi-country study 
on women's health and domestic violence: an observational study. The Lancet, 371(9619), 1165-1172. https://doi.org/10.1016/S0140-6736(08)60522-X

Feder, G. S., Hutson, M., Ramsay, J., \& Taket, A. R. (2006). Women exposed to intimate partner violence: expectations and experiences when they encounter health care professionals: a meta-analysis of qualitative studies. Archives of Internal Medicine, 166(1), 22-37. https:// doi.org/10.1001/archinte.166.1.22

Finkelhor, D., Turner, H., Ormrod, R., \& Hamby, S. L. (2010). Trends in childhood violence and abuse exposure: evidence from 2 national surveys. Archives of Pediatrics \& Adolescent Medicine, 164(3), 238-242. https://doi.org/10.1001/archpediatrics.2009.283

Follingstad, D. R. \& Rogers, M. J. (2014). The nature and prevalence of partner psychological abuse in a national sample of adults. Violence and Victims, 29(1), 3-23. https://doi. org/10.1891/0886-6708.09-160

Freeman, M. D. (1980). Violence against women: does the legal system provide solutions or itself constitute the problem? British Journal of Law and Society, 7(2), 215-241. https://doi. org/10.2307/1409661

Garcia-Moreno, C., Heise, L., Jansen, H. A., Ellsberg, M., \& Watts, C. (2005). Violence against Women. Science, 310(5752), 1282-1283. https://doi.org/10.1126/science.1121400

García-Moreno, C., Zimmerman, C., Morris-Gehring, A., Heise, L., Amin, A., Abrahams, N., . . Watts, C. (2015). Addressing violence against women: a call to action. The Lancet, 385(9978), 1685-1695. https://doi.org/10.1016/S0140-6736(14)61830-4

Gondolf, E. W. (1988). Who are those guys? Toward a behavioral typology of batterers. Violence and Victims, 3(3), 187-203.

Gordon, M. (2000). Definitional Issues in Violence Against Women Surveillance and Research from a Violence Research Perspective. Violence against Women, 6(7), 747-783. https://doi. org/10.1177/10778010022182137

Gottman, J. M., Jacobson, N. S., Rushe, R. H., \& Shortt, J. W. (1995). The relationship between heart rate reactivity, emotionally aggressive behavior, and general violence in batterers. Journal of Family Psychology, 9(3), 227. https://doi.org/10.1037/0893-3200.9.3.227

Gwartney-Gibbs, P. A., Stockard, J., \& Bohmer, S. (1987). Learning courtship aggression: The influence of parents, peers, and personal experiences. Family Relations, 276-282. https:// doi.org/10.2307/583540

Hamberger, L. K. \& Hastings, J. E. (1986). Personality correlates of men who abuse their partners: A cross-validation study. Journal of Family Violence, 1(4), 323-341. https://doi.org/10.1007/ BF00978276

Hamberger, L. K., Lohr, J. M., Bonge, D., \& Tolin, D. F. (1996). A large sample empirical typology of male spouse abusers and its relationship to dimensions of abuse. Violence and Victims, 11(4), 277-292.

Hegarty, K., Hindmarsh, E. D., \& Gilles, M. T. (2000). Domestic violence in Australia: definition, prevalence and nature of presentation in clinical practice. The Medical Journal of Australia, 173(7), 363-367.

Henderson, A. D. (2002). Nurses and workplace violence: nurses' experiences of verbal and physical abuse at work. Nursing Leadership (Toronto, Ont.), 16(4), 82-98. https://doi. org/10.12927/cjnl.2003.16263

Hindin, M. J., Kishor, S., \& Ansara, D. L. (2008). Intimate partner violence among couples in 10 DHS countries: predictors and health outcomes.

Hoffman, K. L. \& Edwards, J. N. (2004). An integrated theoretical model of sibling violence and abuse. Journal of Family Violence, 19(3), 185-200. https://doi.org/10.1023/ B:JOFV.0000028078.71745.a2 
Holtzworth-Munroe, A. (2000). A typology of men who are violent toward their female partners: making sense of the heterogeneity in husband violence. Current Directions in Psychological Science, 9(4), 140-143. https://doi.org/10.1111/1467-8721.00079

Holtzworth-Munroe, A., Meehan, J. C., Herron, K., Rehman, U., \& Stuart, G. L. (2000). Testing the Holtzworth-Munroe and Stuart (1994) batterer typology. Journal of Consulting and Clinical Psychology, 68(6), 1000. https://doi.org/10.1037/0022-006X.68.6.1000

Holtzworth-Munroe, A. \& Stuart, G. L. (1994). Typologies of male batterers: three subtypes and the differences among them. Psychological Bulletin, 116(3), 476. https://doi. org/10.1037/0033-2909.116.3.476

Hunnicutt,G.(2009).Varietiesofpatriarchyand violenceagainstwomen:Resurrecting "patriarchy" as a theoretical tool. Violence against Women. https://doi.org/10.1177/1077801208331246

Jin, X., Eagle, M., \& Yoshioka, M. (2007). Early exposure to violence in the family of origin and positive attitudes towards marital violence: Chinese immigrant male batterers vs. controls. Journal of Family Violence, 22(4), 211-222. https://doi.org/10.1007/s10896-007-9073-3

Johnson, M. P. (1995). Patriarchal terrorism and common couple violence: Two forms of violence against women. Journal of Marriage and the Family, 283-294. https://doi.org/10.2307/353683

Johnson, M. P. (2001). Conflict and control: Symmetry and asymmetry in domestic violence. Couples in Conflict, 95-104.

Johnson, M. P. (2006). Violence and Abuse in Personal Relationships: Conflict, Terror, and Resistance in Intimate Partnerships.

Kilpatrick, D. G. (2004). What is violence against women defining and measuring the problem. Journal of Interpersonal Violence, 19(11), 1209-1234. https://doi. org/10.1177/0886260504269679

Kolesov, V. (2007). Domostroy, Moscow: Eksmo.

Krug, E. G., Mercy, J. A., Dahlberg, L. L., \& Zwi, A. B. (2002). The world report on violence and health. The Lancet, 360(9339), 1083-1088. https://doi.org/10.1016/S0140-6736(02)11133-0

Kruh, I. P., Frick, P. J., \& Clements, C. B. (2005). Historical and personality correlates to the violence patterns of juveniles tried as adults. Criminal Justice and Behavior, 32(1), 69-96. https://doi.org/10.1177/0093854804270629

Langhinrichsen-Rohling, J., Huss, M. T., \& Ramsey, S. (2000). The clinical utility of batterer typologies. Journal of Family Violence, 15(1), 37-53. https://doi.org/10.1023/A:1007597319826

LeBlanc, M. M. \& Kelloway, E. K. (2002). Predictors and outcomes of workplace violence and aggression. Journal of Applied Psychology, 87(3), 444. https://doi.org/10.1037/00219010.87.3.444

Leonard, K. E. \& Senchak, M. (1996). Prospective prediction of husband marital aggression within newlywed couples. Journal of Abnormal Psychology, 105(3), 369. https://doi. org/10.1037/0021-843X.105.3.369

Lewis, S. F. \& Fremouw, W. (2001). Dating violence: A critical review of the literature. Clinical Psychology Review, 21(1), 105-127. https://doi.org/10.1016/S0272-7358(99)00042-2

Löbmann, R., Greve, W., Wetzels, P., \& Bosold, C. (2003). Violence against women: Conditions, consequences, and coping. Psychology, Crime and Law, 9(4), 309-331. https://doi. org $/ 10.1080 / 1068316021000054328$

Maiuro, R. D. (2001). Psychological abuse in violent domestic relations: Springer Publishing Company.

McFeely, C., Whiting, N., Lombard, N., \& McGowan, M. (2013). Domestic Abuse and Gender Inequality: An overview of the current debate. Retreived from: https://www.era.lib.ed.ac. uk/handle/1842/8769, 2018

McMahon, M. \& Pence, E. (1996). Replying to Dan O’Leary. Journal of Interpersonal Violence, 11(3), 452-455. https://doi.org/10.1177/088626096011003012 
Mihalic, S. W. \& Elliott, D. (2005). A social learning theory model of marital violence. Readings in Family Theory, 98.

Moyer, V. A. (2013). Screening for intimate partner violence and abuse of elderly and vulnerable adults: US preventive services task force recommendation statement. Annals of Internal Medicine, 158(6), 478-486. https://doi.org/10.7326/0003-4819-158-6-201303190-00588

Myers, D. L. (1995). Eliminating the battering of women by men: Some considerations for behavior analysis. Journal of Applied Behavior Analysis, 28(4), 493-507. https://doi.org/10.1901/ jaba.1995.28-493

Nagae, M. \& Dancy, B. L. (2010). Japanese women's perceptions of intimate partner violence (IPV). Journal of Interpersonal Violence, 25(4), 753-766. https://doi. org $/ 10.1177 / 0886260509334413$

Nixon, R. D. V., Resick, P. A., \& Nishith, P. (2004). An exploration of comorbid depression among female victims of intimate partner violence with posttraumatic stress disorder. Journal of Affective Disorders, 82(2), 315-320. https://doi.org/10.1016/j.jad.2004.01.008

O'Leary, K. D., Smith Slep, A. M., \& O'Leary, S. G. (2007). Multivariate models of men's and women's partner aggression. Journal of Consulting and Clinical Psychology, 75(5), 752. https://doi.org/10.1037/0022-006X.75.5.752

O’Moore, M. (2006). Defining violence: Towards a pupil-based definition. NoVAS RES CONNECT Initiative.

Organization, W. H. (2013). Responding to intimate partner violence and sexual violence against women: WHO clinical and policy guidelines: World Health Organization.

Parks, S. E., Kim, K. H., Day, N. L., Garza, M. A., \& Larkby, C. A. (2011). Lifetime self-reported victimization among low-income, urban women: The relationship between childhood maltreatment and adult violent victimization. Journal of Interpersonal Violence, 26(6), 11111128. https://doi.org/10.1177/0886260510368158

Petersen, R., Moracco, K. E., Goldstein, K. M., \& Clark, K. A. (2005). Moving beyond disclosure: women's perspectives on barriers and motivators to seeking assistance for intimate partner violence. Women \& Health, 40(3), 63-76. https://doi.org/10.1300/J013v40n03_05

Plichta, S. B. \& Falik, M. (2001). Prevalence of violence and its implications for women's health. Women's Health Issues, 11(3), 244-258. https://doi.org/10.1016/S1049-3867(01)00085-8

Popova, I. (2012). Opyt issledovaniya problemy semeynogo nasiliya. [Experience in the study of the problem of family violence], Nauchnyy dialog (4).

Rhatigan, D. L., Moore, T. M., \& Street, A. E. (2005). Reflections on partner violence: 20 years of research and beyond. Journal of Interpersonal Violence, 20(1), 82-88. https://doi. org/10.1177/0886260504268599

Riggs, D. S., Caulfield, M. B., \& Street, A. E. (2000). Risk for domestic violence: Factors associated with perpetration and victimization. Journal of clinical psychology, 56(10), 1289-1316. https://doi.org/10.1002/1097-4679(200010)56:10<1289::AID-JCLP4>3.0.CO;2-Z

Riggs, D. S. \& O'Leary, K. D. (1996). Aggression between heterosexual dating partners an examination of a causal model of courtship aggression. Journal of Interpersonal Violence, 11(4), 519-540. https://doi.org/10.1177/088626096011004005

Robinson, A. L. (2006). The Dyn Project: Supporting men experiencing domestic abuse. Final Evaluation Report.

Romito, P., Molzan Turan, J., \& De Marchi, M. (2005). The impact of current and past interpersonal violence on women's mental health. Social Science \& Medicine, 60(8), 1717-1727. https://doi.org/10.1016/j.socscimed.2004.08.026

Sagrestano, L. M., Heavey, C. L., \& Christensen, A. (1999). Perceived power and physical violence in marital conflict. Journal of Social Issues, 55(1), 65-79. https://doi.org/10.1111/00224537.00105 
Sellers, C. S., Cochran, J. K., \& Branch, K. A. (2005). Social learning theory and partner violence: A research note. Deviant Behavior, 26(4), 379-395. https://doi.org/10.1080/016396290931669

Shook, N. J., Gerrity, D. A., Jurich, J., \& Segrist, A. E. (2000). Courtship violence among college students: A comparison of verbally and physically abusive couples. Journal of Family Violence, 15(1), 1-22. https://doi.org/10.1023/A:1007532718917

Smith, D. (2012). A new response to youth crime: Routledge.

Smith-Pittman, M. H. \& McKoy, Y. D. (1999). Workplace violence in healthcare environments. Paper presented at the Nursing Forum. https://doi.org/10.1111/j.1744-6198.1999.tb00988.x

Straus, M. A. (1977a). Sexual inequality, cultural norms and wife beating. Sage Yearbooks in Women Policy Studies, 2.

Straus, M. A. (1977b). Wife beating: How common and why? Victimology.

Straus, M. A., Gelles, R. J., \& Steinmetz, S. K. (1980). Behind closed doors: Violence in the American family: Transaction Publishers.

Sugarman, D. B. \& Frankel, S. L. (1996). Patriarchal ideology and wife-assault: A meta-analytic review. Journal of Family Violence, 11(1), 13-40. https://doi.org/10.1007/BF02333338

Swahn, M. H. \& Donovan, J. E. (2004). Correlates and predictors of violent behavior among adolescent drinkers. Journal of Adolescent Health, 34(6), 480-492. https://doi.org/10.1016/ S1054-139X(03)00368-9

Thompson, R. S., Bonomi, A. E., Anderson, M., Reid, R. J., Dimer, J. A., Carrell, D., \& Rivara, F. P. (2006). Intimate partner violence: Prevalence, types, and chronicity in adult women. American Journal of Preventive Medicine, 30(6), 447-457. https://doi.org/10.1016/j. amepre.2006.01.016

Tjaden, P. (2004). What is violence against women? Defining and measuring the problem: A response to Dean Kilpatrick. Journal of Interpersonal Violence, 19(11), 1244-1251. https:// doi.org/10.1177/0886260504269681

Vanderende, K., Mercy, J., Shawa, M., Kalanda, M., Hamela, J., Maksud, N., ...\& Hillis, S. (2016). Violent experiences in childhood are associated with men's perpetration of intimate partner violence as a young adult: a multistage cluster survey in Malawi. Annals of epidemiology, 26(10), 723-728. https://doi.org/10.1016/j.annepidem.2016.08.007

Vung, N. D. \& Krantz, G. (2009). Childhood experiences of interparental violence as a risk factor for intimate partner violence: a population-based study from northern Vietnam. Journal of Epidemiology and Community Health, 63(9), 708-714. https://doi.org/10.1136/ jech.2008.076968

Waltz, J., Babcock, J. C., Jacobson, N. S., \& Gottman, J. M. (2000). Testing a typology of batterers. Journal of Consulting and Clinical Psychology, 68(4), 658. https://doi.org/10.1037/0022006X.68.4.658

Wareham, J., Boots, D. P., \& Chavez, J. M. (2009). A test of social learning and intergenerational transmission among batterers. Journal of Criminal Justice, 37(2), 163-173. https:// doi.org/10.1016/j.jcrimjus.2009.02.011

Whitaker, D. J., Morrison, S., Lindquist, C., Hawkins, S. R., O’Neil, J. A., Nesius, A. M., ... \& Reese, L. R. (2006). A critical review of interventions for the primary prevention of perpetration of partner violence. Aggression and Violent Behavior, 11(2), 151-166. https://doi. org/10.1016/j.avb.2005.07.007

White, J. W. \& Koss, M. P. (1991). Courtship violence: Incidence in a national sample of higher education students. Violence and Victims, 6(4), 247.

White, J. W., Merrill, L. L., \& Koss, M. P. (2001). Predictors of premilitary courtship violence in a Navy recruit sample. Journal of Interpersonal Violence, 16(9), 910-927. https://doi. org/10.1177/088626001016009004 
Whitfield, C. L., Anda, R. F., Dube, S. R., \& Felitti, V. J. (2003). Violent childhood experiences and the risk of intimate partner violence in adults: Assessment in a large health maintenance organization. Journal of Interpersonal Violence, 18(2), 166-185. https://doi. org/10.1177/0886260502238733

Wilkinson, D. L. \& Hamerschlag, S. J. (2005). Situational determinants in intimate partner violence. Aggression and Violent Behavior, 10(3), 333-361. https://doi.org/10.1016/j. avb.2004.05.001

Winstok, Z. (2007). Toward an interactional perspective on intimate partner violence. Aggression and Violent Behavior, 12(3), 348-363. https://doi.org/10.1016/j.avb.2006.12.001

World Health Organization. (1996a). Global consultation on violence and health. Violence: a public health priority. Geneva: WHO.

World Health Organization. (1996b). WHO Global Consultation on Violence and Health. Violence: a public health. Geneva. Retrieved from: http://www.who.int/violenceprevention/approach/definition/en, 2018.

World Health Organization. (2002). The world health report 2002: reducing risks, promoting healthy life: World Health Organization.

World Health Organization. (2013). Global and regional estimates of violence against women: prevalence and health effects of intimate partner violence and non-partner sexual violence: World Health Organization.

Yllö, K. (1983). Sexual equality and violence against wives in American states. Journal of Comparative Family Studies, 67-86.

Yllö, K. (1988). Political and methodological debates in wife abuse research. An earlier draft of this chapter was presented at the 1986 National Council on Family Relations Theory and Methods Workshop, Dearborn, Michigan.

Zabelina, T. (2008). Domashneye nasiliye v otnoshenii zhenshchin: gosudarstvennaya problema ili «lichnoye delo»? [Domestic violence against women: a state problem or a "personal matter"?]. Zhenshchina v rossiyskom obshchestve (4).

Original manuscript received December 26, 2017 Revised manuscript accepted August 16, 2018 First published online September 30, 2018 